\title{
Analysis of Complications after Reconstruction of Bone Defects Involving Complete Mandibular Resection Using Finite Element Modelling
}

\author{
Jutta Markwardt ${ }^{\mathrm{a}} \quad$ Günther Pfeifer ${ }^{\mathrm{b}} \quad$ Uwe Eckelt $^{\mathrm{a}} \quad$ Bernd Reitemeier $^{\mathrm{c}}$ \\ ${ }^{a}$ Klinik für Mund-, Kiefer- und Gesichtschirurgie, \\ ${ }^{\mathrm{b}}$ Institut für Akustik und Sprachkommunikation, \\ c Poliklinik für Zahnärztliche Prothetik, Technische Universität Dresden, Germany
}

\section{Key Words}

Mandibulectomy, segmental · Reconstruction plate .

Plate complications · Plate form · Screw loosening

\section{Summary}

Background: In a retrospective study, risk factors for complications after the bridging of mandibular defects using reconstruction plates were reviewed. Especially the loosening of the plate-screw-mandible complex should be analyzed with a finite element model in order to reduce plate complications in future. Patients and Methods: We examined 60 patients who underwent a treatment with reconstruction plates after tumor resection during a period of 10 years. The problem of screw loosening was additionally reviewed by means of a finite element study, and a model for the loosening process was developed. Results: Our postoperative examination showed that 26 patients suffered from complications that required an early removal of the plate. These complications were oral or extraoral plate exposures, the looseness of screws with or without plate displacement, and plate fractures. Thereby, we noticed that maxillary and mandibular areas of opposing teeth, the size of the mandible defect, and the crossing of the orofacial midline are all risk factors for plate complications. On the basis of the finite element model, a modified arrangement of the screws was derived. Hence, a new type of resection plate was established. Conclusions: By repositioning the screw holes along the long axis of the plate, the transition from tensile force to torque force of the screws in the screw-plate-bone complex can be minimized. Thereby, the complication of screw loosening will be considerably reduced.

\author{
Schlüsselwörter \\ Unterkieferteilresektion - Rekonstruktionsplatte · Platten- \\ komplikationen · Plattenform - Schraubenlockerung
}

\section{Zusammenfassung}

Hintergrund: In einer retrospektiven Studie wurden Risikofaktoren für Komplikationen nach Überbrückung von Unterkieferdefekten mit Rekonstruktionsplatten geprüft. Insbesondere die Lockerungsvorgänge des SchraubenPlatten-Unterkiefer-Verbundes sollten mit einer FiniteElemente-Modellierung analysiert werden, um in Zukunft eine Reduzierung der Plattenkomplikationen erreichen zu können. Patienten und Methoden: Es wurden 60 Patienten untersucht, welche im Zeitraum von 10 Jahren im Rahmen von Tumoroperationen mit Rekonstruktionsplatten versorgt wurden. Das Problem der Lockerung der Plattenschrauben wurde zusätzlich mittels einer FiniteElemente-Studie überprüft und ein Modell für den Lockerungsvorgang erarbeitet. Ergebnisse: Die Nachuntersuchungen ergaben, dass bei 26 Patienten die Platte wegen Komplikationen vorzeitig entfernt werden musste. Die Komplikationen traten als orale und extraorale Plattenfreilage, als Schraubenlockerung ohne oder mit Plattendislokationen und als Plattenbrüche auf. Dabei konnte festgestellt werden, dass bestehende Stützzonen des körpereigenen Restgebisses, die Größe des Unterkieferdefektes und dessen Mittellinienüberschreitung Risikofaktoren für Plattenkomplikationen darstellen. Anhand der Finite-Elemente-Modellierung wurde eine veränderte Schraubenanordnung abgeleitet. Daraus resultiert eine neue Form der Resektionsplatte. Schlussfolgerungen: Durch die Verschiebung der Schraubenlöcher aus der Längsachse der Platte kann der Übergang von der Zugbelastung zur Drehmomentbelastung der Schrauben im Schrauben-Platten-Knochen-Verbund der Platte minimiert werden. Dadurch werden Schraubenlockerungen als Komplikationen wesentlich seltener auftreten.

\begin{tabular}{ll}
\hline KARGER & ( ) 2007 S. Karger GmbH, Freiburg \\
Fax +49 7614520714 & Accessible online at: \\
$\begin{array}{l}\text { E-mail Information@Karger.de } \\
\text { www.karger.com }\end{array}$ & www.karger.com/onk \\
&
\end{tabular}

Dr. med. Dr. med. dent. Jutta Markwardt

Universitätsklinikum der Technischen Universität Dresden

Klinik für Mund-, Kiefer- und Gesichtschirurgie

Fetscherstraße 74, 01307 Dresden, Germany

Tel. +49 351 458-3382, Fax -5348

E-mail Jutta.Markwardt@mailbox.tu-dresden.de 


\section{Introduction}

Mandible defects without immediate reconstruction of the discontinuity might lead to disturbances of mastication and swallowing. Along with speech impairment, normal mandibular range of motion and breathing might also be affected. Deficits in the external anatomy and appearance of the face may be observed [1]. These common ailments might be prevented by immediate reconstruction of the submandibular defect using free or vascular pedicled bone transplants as well as by implementing resection plates [2]. Common complications, such as plate fracture, screw or plate loosening, and/or oral or extraoral plate exposure have been observed in the use of titanium reconstruction plates [3-8]. In most cases these complications require the removal of the plate.

The goal of this study was to reduce the number of complications following the implantation of titanium plates by analyzing the reasons for plate loss. Using the finite element model, the process of screw loosening within the plate-screwmandible complex was displayed experimentally and analyzed. Finally, a modification of the shape of the reconstruction plate was developed.

\section{Patients and Methods}

Sixty patients with tumor diseases underwent a mandibular arch resection with separation of the continuity at the Department of Oral and Maxillofacial Surgery at Dresden University of Technology between 1991 and 2001. The resulting bone defects were bridged with titanium resection plates.

The patient group consisted of 44 men and 16 women. The patients' mean age was 55.6 and 60.9 years, respectively. In 59 cases patients suffered from tumors of the oral cavity; in 1 case the patient suffered from a tumor of the skin of the cheek.

The mandible defects are assigned to 5 groups according to the corre sponding region (fig. 1, A-E): $\mathrm{A}$ - ascending mandible and angle of the ramus to the premolar region of the same side; $\mathrm{B}$ - ascending mandible and angle of the ramus to the anterior region of the same side; $\mathrm{C}$ - ascending mandible and angle of the ramus to the contralateral side (across the midline); D - condylar process (processus condylaris) to the anterior region without crossing the midline; $\mathrm{E}$ - interforaminally (anterior region between right and left mental foramina (foramina mentalia).

Three different plate shapes were implanted: The 'SORG system' (mandible reconstruction system; Martin Medizintechnik, Tuttlingen, Germany) was used in 28 patients; the 'Würzburger reconstruction plate' (Leibinger, Freiburg, Germany) was implanted 30 times; and the 'AOresection plate' (Straumann Institutes AG, Dept. Synthes, Waldenburg, Switzerland) was used in 2 cases. The particular plate system was applied according to the manufacturer's specification and according to the corresponding instrument

Soft-tissue defects in the area of the floor of the mouth, the tongue, the mandible alveolar bone, the buccal mucosa, and the peritonsillar region were covered either by local tissue, by a pedicled lobe plastic technique, or by microsurgical soft-tissue transplantation. When the defect could not be closed with the soft tissue in the area of the defect, shifting and lobe plastic techniques were employed. The pedicled approaching flap technique was performed using the nasal-labial lobe. Additionally, the pedicled myocutaneous distal flap technique was performed using the pectoralis

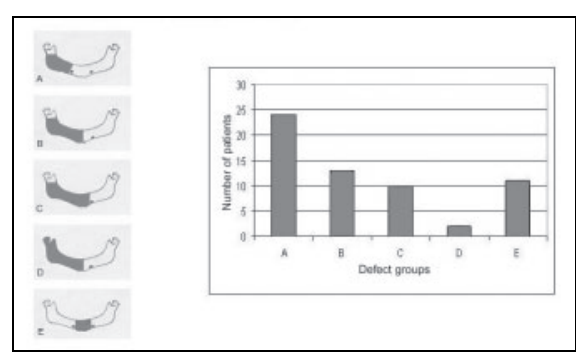

Fig. 2. Screw loosening; intraoperative site with the surface of the mandibular bone and the screwed plate.

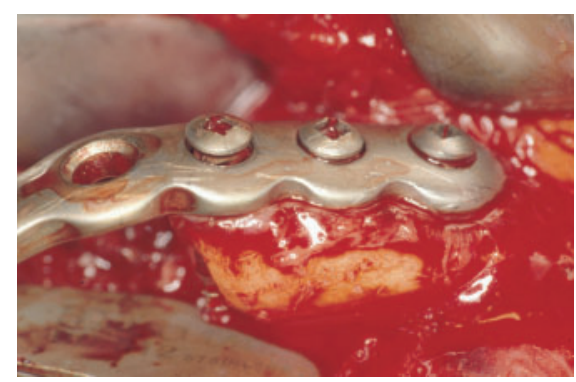

isle flap in 13 cases and the temporal flap in 2 cases. Finally, using the microsurgical technique, the distal radial forearm flap was transplanted in 6 patients, the myocutaneous latissimus dorsi flap in 1 patient, and the jejunal flap in 7 patients; respectively. All cases included in our examinations did not show any healing disorders of the flaps.

The postoperative examination of the teeth revealed that 20 patients were edentulous. The remaining patients were partially edentulous in either the maxilla or mandible or in both arches. Eichner's classification of regions of mandibular and maxillary opposing teeth deals with a functional orientation of teeth in partially edentulous occlusion. According to the group classification of partially edentulous arches by Eichner [9], we could assign no patient to group A, 26 patients were assigned to group B, and 34 patients to group C.

In terms of the complex oncological treatment, 49 of the 60 patients received radiation therapy. Of those 49 patients, 14 were irradiated preoperatively and 23 postoperatively. 11 patients received both pre- and postoperative radiation. Additionally, 1 patient was treated with a combination of radiation and chemotherapy.

All patients underwent a standardized follow-up. The medical records from December 1991 to September 2003 were also analyzed. The time of the incorporation of the plate, the onset of any complications, and the time interval between surgery and the scheduled plate removal followed by mandible reconstruction via bone transplantation were recorded.

During the removal of the plates we regularly observed the looseness of screws as depicted in figure 2. This figure shows the intraoperative site with the surface of the mandibular bone and the screwed plate. All three visible screws were loose. The screw closest to the defect was found to have the greatest amount of looseness. As the screws become loose and the whole plate also becomes loose, ultimately, a granulation tissue develops between the plate and the mandibular bone. The plate movement leads to bone erosions and the deposition of granulation tissue between the plate and the mandibular bone.

\section{Statistical Analysis}

A follow-up analysis was performed using SAS software (SAS/STAT User's Guide, Version 9, SAS Institute Inc., Cary, NC, USA, 2006). Major event was defined as the onset of any complications following the bridging of mandible defects by reconstruction plates. All patients reached one of three concurrent events or they were considered to be censored (e.g. due 
Table 1. Assignment of plate complications according to the defect groups (A-E)

\begin{tabular}{llllll}
\hline $\begin{array}{l}\text { Defect } \\
\text { group }\end{array}$ & $\begin{array}{l}\text { Plate } \\
\text { fracture }\end{array}$ & $\begin{array}{l}\text { Plate } \\
\text { loosening }\end{array}$ & $\begin{array}{l}\text { Plate } \\
\text { exposure }\end{array}$ & $\begin{array}{l}\text { Sum of } \\
\text { complications/ } \\
\text { sum of plates }\end{array}$ & $\begin{array}{l}\text { Sum, } \\
\%\end{array}$ \\
\hline A & 1 & 6 & 1 & $8 / 24$ & 33 \\
B & 0 & 3 & 2 & $5 / 13$ & 38 \\
C & 1 & 1 & 5 & $7 / 10$ & 70 \\
D & 0 & 0 & 1 & $1 / 2$ & 50 \\
E & 0 & 1 & 4 & $5 / 11$ & 45 \\
\hline
\end{tabular}

to death, loss during follow-up, no observable complications) at the time of the last follow-up.

\section{Experimental Approach}

In order to investigate possible causes for the loosening of the plate screws and to reach a uniform force distribution among the screws, we performed a finite element study using the finite element program ANSYS 5.3 (Ansys, Inc. Southpointe, 275 Technology Drive Canonsburg, PA 15317, USA). A simplified model of the resection plate that crossed the midline was chosen for a load-bearing capacity analysis.

\section{Results}

Twenty-six complications related to the implanted plates were recorded in 60 patients $(43 \%)$. We observed 13 oral or extraoral plate exposures, the looseness of the screws or the whole plate in 11 cases, and a plate fracture in 2 patients. When investigations of the localization and the extent of the mandible defects were performed, analysis revealed that the most frequent defects occurred in the region of the ascending mandible to the premolar region (group A). Groups A and B showed the highest occurrence of screw and plate looseness, whereas the exposure of the plate occurred mostly in groups $\mathrm{C}$ and $\mathrm{E}$ (table 1).

The analysis also included radiation and chemotherapy. 48 out of 60 patients received radiation therapy; 22 of the irradiated patients suffered from complications.

The chi-square test (SPSS 11.5) results in $\mathrm{p}=0.526$, so that there is no significant difference concerning the radiation therapy and the complications.

Analysis of the ratio of remaining teeth after segmental mandibulectomy and premature plate loss revealed that out of 26 patients affected, 12 had a remaining tooth in either the maxilla or mandible with at least 1 to 3 regions of opposing teeth. 9 patients were edentulous or had only single teeth without the presence of opposing teeth. The most important results are depicted in table 2 . These results show that the problem of oral or extraoral plate exposure is not dependent on the number of remaining teeth, including regions of opposing teeth. Larger mandible defects crossing the midline (defect groups $\mathrm{C}$ and $\mathrm{E}$ ) are considered to be a higher risk factor for
Table 2. Relation of plate complication, defect group, and regions of opposing teeth

\begin{tabular}{|c|c|c|c|c|c|c|c|c|}
\hline \multirow[t]{2}{*}{$\begin{array}{l}\text { Defect } \\
\text { group }\end{array}$} & \multirow[t]{2}{*}{$\begin{array}{l}\text { Plate com- } \\
\text { plications, } n\end{array}$} & \multicolumn{7}{|c|}{$\begin{array}{l}\text { Regions of opposing teeth } \\
\text { (classification by Eichner, [9]) }\end{array}$} \\
\hline & & B1 & B2 & B3 & B4 & $\mathrm{C} 1$ & $\mathrm{C} 2$ & $\mathrm{C} 3$ \\
\hline & plate break & & & & & & & \\
\hline A & 1 & & 1 & & & & & \\
\hline \multicolumn{9}{|l|}{ B } \\
\hline $\mathrm{C}$ & 1 & & & & 1 & & & \\
\hline \multicolumn{9}{|l|}{$\mathrm{D}$} \\
\hline \multicolumn{9}{|l|}{$\mathrm{E}$} \\
\hline & \multirow{2}{*}{\multicolumn{8}{|c|}{$\begin{array}{l}\text { screw and plate } \\
\text { loosening }\end{array}$}} \\
\hline & & & & & & & & \\
\hline A & 6 & 1 & & 4 & & & & 1 \\
\hline B & 3 & 1 & 1 & 1 & & & & \\
\hline $\mathrm{C}$ & 1 & & & & & 1 & & \\
\hline \multicolumn{9}{|l|}{$\mathrm{D}$} \\
\hline \multirow[t]{3}{*}{$\mathrm{E}$} & 1 & & & 1 & & & & \\
\hline & plate & & & & & & & \\
\hline & exposures & & & & & & & \\
\hline A & 1 & & & & & & & 1 \\
\hline B & 2 & & & & & 1 & & 1 \\
\hline $\mathrm{C}$ & 5 & & 1 & 1 & & & 2 & 1 \\
\hline $\mathrm{D}$ & 1 & & & & & & & 1 \\
\hline $\mathrm{E}$ & 4 & & & & & & 1 & 3 \\
\hline
\end{tabular}

oral exposure of the plate late in the follow-up. The force generated by the muscles of mastication and transferred through the region of the opposing teeth in the maxilla or mandible seems to cause the observed looseness of the screws. Similarly, plate fractures seem to be caused by the presence of opposing teeth on the opposite side of the mandible from plate or by material fatigue due to bending and torsion of the plate during surgical implantation.

The statistical analysis made by estimating the cumulative incidence of concurrent risks shows the risks of plate complications. The lowest risk can be observed for plate fractures, the highest risk for plate exposure and screw looseness. The cumulative incidence of plate exposure and screw loosening follows the same pattern: plate fractures occur late in the follow-up (fig. 3).

The experimental approach, using a simplified model of a reconstruction plate that extended past the midline, revealed two different phases of the loosening process (fig. 4). During the first phase, the force of mastication has a leverage effect on the screw. Assuming a force of $300 \mathrm{~N}$, the tensile force on the screw closest to the defect will be around 1,000 N. The tensile force on the successive screws, depending on the torsion (torque), might be as much as $30 \%$ lower. The initial connecting points of the mandible-plate and the plate-screw complex are depicted in figure 4 via short blue arrows. In the second phase, the tensile force leads to the loosening of the screw. 
Fig. 3. Risks of plate complications: estimation of the cumulative incidence of concurrent risks. Competing risks: - screw loosening; - oral or extraoral plate exposure; … plate fracture.

Fig. 4. Two phases of screw loosening due to components of forces of mastication.

Fig. 5. The new model of the plate.

Fig. 6. Finite element analysis with screws arranged in the middle axis of the plate.

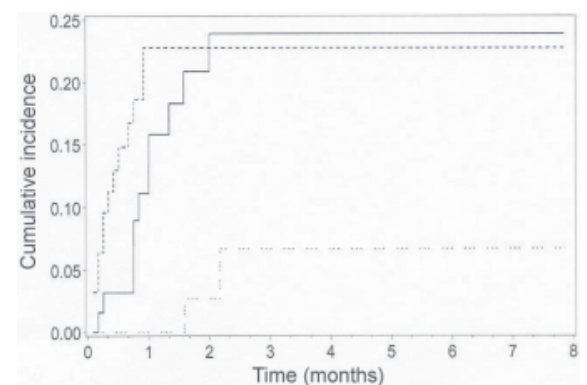

Fig. 7. Finite element analysis with screws displaced from the middle axis in direction to the periphery of the plate.

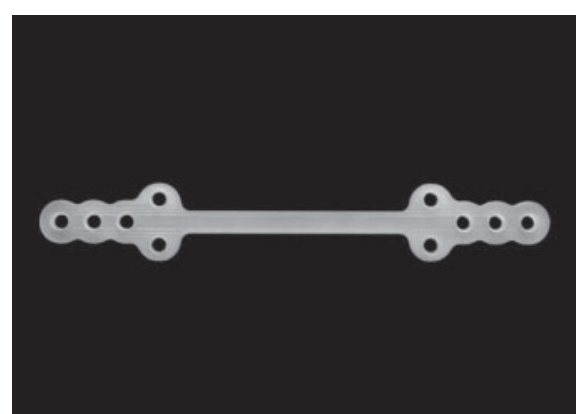

Phase I: loosening due to tension moment due to chewing force, selected

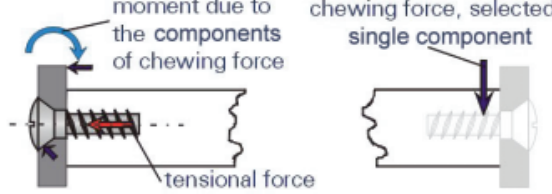

Phase Il: loosening due to surface pressure in the bone

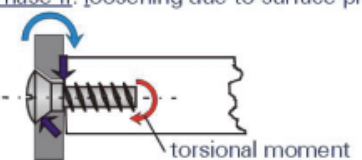

$\downarrow$ crosspoint
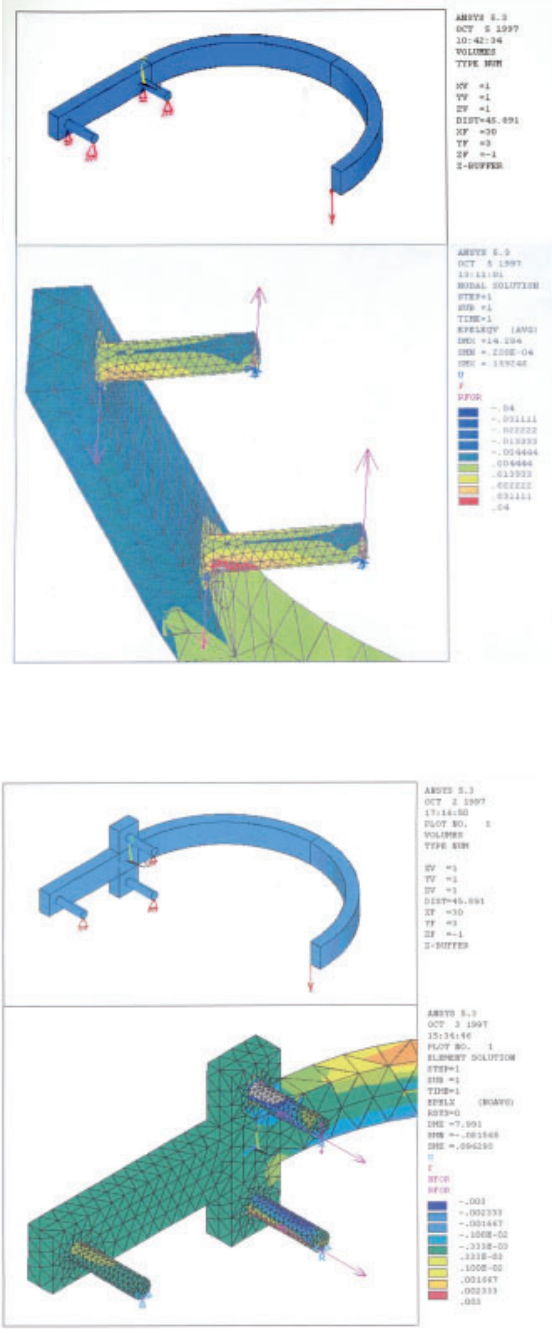

Force is now exerted by the plate on the screw at two points initiating a turning moment (torque) instead of tensile force. The short blue arrows in figure 4 (phase II) depict the connecting points of the plate-screw complex.

These test results have led to a new model of the plate. The position of the screws was adjusted. The shape of the plate and the position of the screw holes were changed. By using the new form, based on the theoretical construct, the transition from tensile force to a torque on the inner screw can now be avoided (fig. 5, 6). Consequently, the screws experience only tensile force. While the force of mastication stays the same, the tensile force can be reduced by an estimated $30 \%$ (fig. 7).

\section{Discussion}

Based on clinical experience won through the surgical removal of mandible resection plates as well as on the results of the experimental approach using the finite element program, it is now possible to extend the duration of plates implanted in the mandible. This extended duration can be achieved by making adjustments in the plate shape, according to current knowledge of mandible biomechanics, thus stabilizing the plate-mandible complex. In 1960 it was discovered that normal functional strain or force on the mandible leads to a deformation of the mandibular arch. Jung [10], Marx [11], and in 2006 Yamashita et. al. [12], also showed that a compression of the mandible in the transverse direction always leads to a rotational motion (torque). Furthermore, it was concluded that a unilateral force on the mandible produces a torque on the mandible. This torque causes a convexity of the mandibular arch on the loaded side and a concavity of the arch on the unloaded side. Surveys of the mechanical parameters of the human mandible and the in vivo reaction of compact bone revealed by Arendts and Sigolotto [13, 14] showed that the reasons for postoperative complications might be due to a change in the biomechanics of bone after the implantation of technical devices (e.g. plates). Vital bone tissue is a complex material system which has the capacity of adjustment (i.e. new modelling), regeneration (i.e. remodelling), and self-healing (i.e. bone fusion). 
Table 3. Reference summary regarding known plate complications

\begin{tabular}{|c|c|c|c|c|c|c|c|c|c|}
\hline \multirow[t]{2}{*}{ Authors } & \multirow[t]{2}{*}{$\begin{array}{l}\text { Number } \\
\text { of cases }\end{array}$} & \multirow[t]{2}{*}{$\begin{array}{l}\text { Study period, } \\
\text { months }\end{array}$} & \multicolumn{2}{|c|}{ Plate exposure } & \multicolumn{2}{|c|}{$\begin{array}{l}\text { Screw and plate } \\
\text { loosening }\end{array}$} & \multicolumn{2}{|c|}{ Plate break } & \multirow[t]{2}{*}{ Sum, \% } \\
\hline & & & $\mathrm{n}$ & $\%$ & $\mathrm{n}$ & $\%$ & $\mathrm{n}$ & $\%$ & \\
\hline Saunders et al., 1990 [20] & 27 & 33 & 12 & 44.4 & 2 & 7.4 & 0 & 0 & 51.8 \\
\hline Ueyama et al., 1996 [19] & 25 & 47 & 6 & 24.0 & 4 & 16.0 & 1 & 4.0 & 44.0 \\
\hline Lindquist et al., 1992 [3] & 34 & 72 & 3 & 8.8 & 3 & 8.8 & 1 & 2.9 & 20.5 \\
\hline del Hoyo et al., 1994 [16] & 25 & 48 & 7 & 28.0 & 2 & 8.0 & 0 & 0 & 36.0 \\
\hline Irish et al., 1995 [17] & 51 & 55 & 4 & 7.8 & 2 & 3.9 & 6 & 11.8 & 23.5 \\
\hline Blackwell et al., 1996 [18] & 15 & 15 & 4 & 26.7 & 0 & 0 & 1 & 6.7 & 33.4 \\
\hline Spencer et al., 1999 [4] & 21 & 48 & 2 & 9.5 & 6 & 28.6 & 0 & 0 & 38.1 \\
\hline Yi et al., 1999 [5] & 97 & 84 & 6 & 6.2 & 22 & 22.7 & 3 & 3.1 & 32.0 \\
\hline v. Minnen et al., 2002 [7] & 36 & 83 & 7 & 19.4 & 8 & 22.2 & 1 & 2.8 & 44.4 \\
\hline Markwardt, 2004 [21] & 60 & 120 & 13 & 21.7 & 11 & 18.3 & 2 & 3.3 & 43.3 \\
\hline
\end{tabular}

Torsion force loads the mandible in a rotational direction, and this force seems to be responsible for loosening the resection plate screws. Excessive loss of the different muscles of mastication combined with the effects of mandible defects, requiring the implantation of adequate resection plates, both contribute to a pattern of forces at work on the mandibular bone and plate attachment area. Another source of torque on the resection plate and the underlying mandibular bone may be the presence of opposing teeth on the opposite side of the mandible from the plate implant. The differences in vertical dimension between the edentulous resection plate region on one side of the arch and the region of opposing teeth on the opposite side of the arch could also be an additional stress at the resection plate attachment. Korioth and Hannam [15] demonstrated by using the finite element program that the forces from regions of opposing teeth can cause mandible deformation.

The problem of plate complications and its effects were also documented by other authors (table 3) [3-5, 7, 16-20]. The clinical follow-up of our patients revealed that loosening of screws and plates occurred in 9 of 11 patients who had 3 or 4 regions of opposing teeth on the intact side of the mandible. The process of plate exposure was observed in 13 patients: 7 of whom were edentulous after the surgical procedure was performed; 4 of whom had only single teeth remaining within the oral cavity without regions of opposing teeth; 2 of whom had 1 or 2 regions of opposing teeth. This finding is most frequent ( 9 of 13 patients) in plates crossing the midline.

Our findings support the conclusion that the presence of opposing teeth, found postoperatively among the remaining teeth, could be considered a risk factor for screw loosening.
The size of the mandible defect and the necessity for crossing the midline are instrumental in the process of plate exposure. Frequent torsion and the presence of opposing teeth also seem to be risk factors for plate fracture.

Plate exposure occurs early in the follow-up compared to the process of screw loosening. Plate fractures have a very late onset. The average time from surgery to plate exposure was 5 months. Average time to plate loosening was 11 months, and to any observable plate fractures, 22 months. The risk factors, especially with regard to plate loosening, have been corroborated by the experimental finite element program.

\section{Conclusions}

Through the force of the muscles of mastication, the different movements of the mandible cause a load on the rigid screwplate-mandible complex. Related to this load is a surface pressure between the reconstruction plate and the screw. The load on the screw changes from a tensile force to a rotational or torque force caused by these various directions of force from the musculature. Initially, the force acts only on the screw closest to the defect. The torque causes the screw to loosen and move out of the bone. For this reason, a modification of the plate in the area of the screw attachment is proposed. The purpose of this plate modification would be to keep the screws under tensile force, thereby preventing a change form tensile force to torque force on the screw closest to the defect. By repositioning the screws along the long axis of the plate, the transition from tensile force to torque force can be minimized (fig. 7). In this way, the risk for a destabilization of the plate by screw loosening can be considerably reduced. 


\section{References}

1 Spiessl B: Internal Fixation of the Mandible - A Manual of AO/ASIF Principles. Berlin, Springer, 1989, pp 156-66.

2 Prein J, Rohner D: Titan in der AO Kiefer- und Gesichtschirurgie; in Wirz J, Bischoff $\mathrm{H}$ (Hrsg) Titan in der Zahnmedizin. Berlin, Quintessenz, 1997, pp 389-97.

3 Lindqvist C, Söderholm A-L, Paatsama J: Rigid reconstruction plates for immediate reconstruction following mandibular resection for malignant tumors. J Oral Maxillofac Surg 1992;50:1158-63.

4 Spencer KR, Sizeland A, Taylor GI, Wiesenfeld D: The use of titanium mandibular reconstruction plates in patients with oral cancer. Int J Ora Maxillofac Surg 1999;28:288-90.

5 Yi Z, Jian-Gou Z, Guang-Yan Y, Ling L, Fu-Yun Z, Guo-Cheng Z: Reconstruction plates to bridge mandibular defects: a clinical and experimental investigation in biomechanical aspects. Int $\mathrm{J}$ Ora Maxillofac Surg 1999;28:445-50.

6 Lindqvist C, Söderholm A-L, Salo A, Subasinghe J, Ylijoki S, Skutnabb K, Hallikainen D: A comparative study on four screw-plate locking systems in sheep: a clinical and radiological study. J Ora Maxillofac Surg 2001;30:160-6.

7 van Minnen B, Nauta JM, Vermey A, Bos RRM, Roodenburg JLN: Long-term functional outcome of mandibular reconstruction with stainless stee AO reconstruction plates. Br J Oral Maxillofac Surg 2002;40:144-8.
8 Gellrich NC, Suarez-Cunqueiro MM, Otero-Cepeda XL, Schon R, Schmelzeisen R, Gutwald R: Comparative study of locking plates in mandibular reconstruction after ablative tumor surgery: THORP versus UniLOCK system. J Oral Maxillofac Surg 2004;62:186-93.

9 Strub J: Curriculum Prothetik. Berlin, Quintessenz, 1999, p 909.

10 Jung F: Die funktionell elastischen Deformationen des Kieferknochens und die Eigenbeweglichkeit der Zähne. Schweiz Monatsschr Zahnheilkd 1960; $17: 70$

11 Marx H: Die funktionsbedingten elastischen Deformierungen der menschlichen Mandibula. Med Habil Schrift, Mainz, 1966.

12 Yamashita J, Wang Q, Dechow PC: Biomechanica effects of fixed partial denture therapy on strain patterns of the mandible. J Prosthet Dent 2006;95: $55-62$.

13 Arendts FJ, Sigolotto C: Standardabmessungen, Elastizitätskennwerte und Festigkeitsverhalten des Human-Unterkiefers, ein Beitrag zur Darstellun der Biomechanik der Unterkiefer - Teil I. Biomed Tech 1989;34:248-55.

14 Arendts FJ, Sigolotto C: Mechanische Kennwerte des Humanunterkiefers und Untersuchung zum 'In-vivo'-Verhalten des kompakten Knochengewebes, ein Beitrag zur Darstellung der Biomechanik des Unterkiefers - Teil II. Biomed Tech 1990; 35:123-30
15 Korioth TWP, Hannam AG: Deformation of the human mandible during simulated tooth clenching. J Dent Res 1994;73:56-66.

16 del Hoyo JA, Sandroman JF, Bueno PR, Gonzales FJD, Usandizaga JLG-D, Gil FM, Gias LN, Lopez AC, Cardozo RM: Primary mandibular reconstruction with bridging plates. J Craniomaxillofac Surg 1994;22:43-8.

17 Irish JC, Gullane PJ, Birt BD, Boyd JB: Primary mandibular reconstruction with the titanium hollow screw reconstruction plate: evaluation of 51 cases. Plast Reconstr Surg 1995;96:93-9.

18 Blackwell KE, Buchbinder D, Urken ML: Latera mandibular reconstruction using soft-tissue free flaps and plates. Arch Otolaryngol Head Neck Surg 1996;122:672-8

19 Ueyama Y, Naitoh R, Yamagata A, Matsumura T Analysis of reconstruction of mandibular defect using single stainless steel A-O reconstruction plates. J Oral Maxillofac Surg 1996;54:858-62.

20 Saunders JR, Hirata RM, Darrell AJ: Definitive mandibular replacement using reconstruction plates. Am J Surg 1990;160:387-9.

21 Markwardt J: Rekonstruktion von Unterkieferdefekten mit Kontinuitätstrennung mittels Rekonstruktionsplatten aus Titan. Med. Diss. TU Dresden, 2004 